\title{
O ser aqui e agora: a ética da situação
}

\author{
Prof. Dr. Josemar Soares ${ }^{1}$
}

Nos textos recentes se trabalharam as temáticas do miricismo cotidiano e do tirocínio racional constante. Este material complementa ambos: é a ética da situação, ou seja, como resolver aqui e agora minhas principais circunstâncias a partir da racionalidade ontológica.

O homem não tem acesso ao Ser em si, a Deus ou o Princípio Absoluto. Na medida em que somos existentes, somos históricos, com início e fim. Existimos como evento, como fenômeno, como acontecimento do Ser. Nós somos entes, finitos, que um dia não existiremos mais, enquanto existirmos, somos fenomenologias do Ser, e por este vínculo temos também uma porta aberta ao infinito, à transcendência metafísica.

No entanto, na medida em que somos existentes, somos jogados ao mundo, tal como Heidegger já definia no conceito de dasein (ser-aí). Ou seja, somos entes relativos, que existimos em um contexto definido, com relações a outros pólos. Cada um de nós existe aqui e agora, com esta condição social, econômica, cultural, com determinada biografia já percorrida, com estas relações afetivas, com modelos de comportamento aprendidos na infância, enfim, carregamos uma série de circunstâncias que já nos limitam, já nos colocam em determinada posição existencial, exigindo de nós atitudes imediatas contra problemas específicos.

Isto quer dizer que somos entes, emanados do Ser Absoluto, mas que ao sermos colocados aqui nos tornamos já partes de um contexto definido. Estou nesta família, nesta empresa, com esta condição financeira, com estas amizades, com este problema a resolver com tal assunto, com esta relação a ser trabalhada, com esta negociação a fazer, etc. Ou seja, ao nos tornarmos história, temos uma série de questões imediatas a serem resolvidas.

\footnotetext{
${ }^{1}$ Josemar Sidinei Soares, Doutor em Filosofia pela Universidade Federal do Rio Grande do Sul (UFRGS), Mestre em Direito pela Universidade do Vale do Itajaí (UNIVALI), é professor do curso de bacharelado em Ontopsicologia e Direito da Faculdade Antonio Meneghetti (AMF).
} 
Aqui entra o conceito de ética da situação, que faz a convergência entre aqueles de miricismo e de tirocínio. Ética da situação quer dizer que aqui e agora, nesta minha condição existencial, tenho algumas decisões a tomar, algumas ações a praticar.

Determinado sujeito, em dado momento, precisa ir ao trabalho, mas ao mesmo tempo tem um problema familiar que o incomoda, além de uma questão contratual financeira a resolver com algum empresário, ou ainda alguma questão em sua saúde que precisa ser verificada no médico. Junte a isto a vontade de fazer determinada viagem, de encontrar outra pessoa, assim por diante. Ou seja, ao mesmo tempo aquele sujeito é tocado por várias relações, mas aqui e agora ele só pode fazer uma, e somente depois de resolver esta poderá mexer e solucionar as demais. Qual ação praticar? Ir ao trabalho? Resolver a questão familiar? Procurar o médico? Agendar com aquele empresário a reunião de negócios? Ignorar tudo e tirar dias de folga?

Enfim, aqui e agora tenho uma diversidade de circunstâncias agindo sobre mim, e preciso ter o discernimento pontual do que deve ser feito, porque para cada instante há a ação adequada.

Voltemos ao Ser. Somos entes, fenomenologias do Ser. Isto é, aqui estamos historicamente, mas ao mesmo tempo temos uma ligação ao Absoluto transcendente, porque por algum motivo ele optou por também se encarnar em nós, assim como se encarnou na árvore, no cavalo, na estrela, no mar, etc.

Isto quer dizer que por mais que sejamos entes históricos, somos também alguém com tensão à transcendência, com tensão ao metafísico. E aqui está o ponto crucial: para além de nossos modelos de família, de nossas religiões, de nossas opiniões, de nossas preferências pessoais, de nossos achismos e gostos, há a volição de realizar a si mesmo, de retornar ao Ser. O Ser quer sempre a realização completa, quer sempre a saída perfeita de cada situação. Em cada contexto, a nossa parte mais íntima, que nos conecta ao Ser, tem a solução otimal. E é uma solução categórica, não estereotipada.

A ética da situação consiste justamente em ler esta solução dada pelo Ser e traduzi-la na decisão acertada aqui e agora.

Cada ente existe de modo egóico, buscando acima de tudo a própria satisfação. Isto significa que cada ente busca sempre e primeiramente salvar a si mesmo, e não a uma instituição, a uma religião, a um estereótipo, a uma ideologia, etc.

Sendo assim, a cada contexto devemos olhar profundamente para o íntimo de nós mesmos e verificar qual das circunstâncias toca imediatamente de modo mais 
impactante a minha condição tanto existencial quanto ôntica. E isto é como dizia Heráclito, muda continuamente, porque varia como está a saúde, como está a condição financeira, como está a relação com as pessoas-chaves, etc. Se as questões mínimas da existência não estão trabalhadas e ordenadas é difícil esperar saltos maiores, realização de ambições maiores. Aqui entra o miricismo, primeiro resolver cada aspecto, cada detalhe de nossa vida, e depois, pouco a pouco ir mexendo nas questões maiores. Não há salto na existência, tudo se faz de modo ordenado, tijolo a tijolo, com paciência, perseverança.

Portanto, o tirocínio racional constante nada mais é do que identificar a ética da situação, colher aqui e agora o que mais afeta minha dignidade, minha expectativa de autorrealização, minha vida com satisfação. E aí, com a frieza de quem busca salvar a si mesmo, tomar as decisões assertivas necessárias, fazendo as ações que forem precisas. Porque não é importante salvar o mundo, a instituição, a sociedade, e sim prioritário é salvar a si mesmo. O restante vem anexo, se desenvolve junto, pois na medida em que o homem cresce, também o ambiente no qual ele interage cresce, afinal somos entes sociais, existimos já dentro de contextos em relações com outros.

Isto tudo nada mais é do que aplicação prática da racionalidade ontológica, saber identificar aqui e agora o que é essencial e discernir daquilo que é acidental na minha vida. O que é essencial fazer agora? E qual a decisão essencial a ser feita sobre este assunto? O que é acidental e estou dando afeto demais, interesse demais? Estou agindo sobre o núcleo essencial ou sobre demandas secundárias?

Enfim, ética da situação é mapear todas as circunstâncias que me tocam hoje e discernir o essencial, a decisão correta de como agir em cada aspecto e na ordem de importância que elas merecem. E a ordem de importância não é definida pelas minhas preferências pessoais, mas pelo impacto que elas causam em minha dignidade existencial e expectativa de autorrealização aqui e agora. 